1 Department of Primary Care \& Public Health, Imperial College London, London, UK

2 Faculty of Epidemiology and Population Health, London School of Hygiene and Tropical Medicine Keppel St, London, UK

3 Norfolk and Norwich University Hospitals, Colney Ln, Colney, Norwich, UK

4 Sudan Doctors Union UK

Twitter @itasnimeo @sarajalilo Cite this as: BMJ2022;376:0241 http://dx.doi.org/10.1136/bmj.0241 Published: 28 January 2022

\title{
Militia-led attacks on health facilities and workers in Sudan
}

\author{
These authors issue an urgent call to action to end attacks on healthcare workers and facilities, \\ ensuring the right to health for all Sudanese people
}

\author{
Tasnime Osama, ${ }^{1}$ Maysoon Dahab, ${ }^{2}$ Sara Abdelgalil 3,4
}

Sudan's history has been shaped by popular resistance against authoritarian rule. When regimes are challenged, suppression is often translated into deliberate attacks on health facilities and workers. Clinging onto power, the paramilitary Rapid Support Forces (RSF)-an extension of Al-Bashir's Janjaweed militias-are responsible for war crimes in Darfur and systematic attacks on health. ${ }^{1}$ Throughout the 2018-2019 pro-democracy revolution, the military and RSF repeatedly targeted hospitals and clinics using live ammunition, injuring and killing hundreds of people. ${ }^{2}$ Hospitals were invaded, emergency services were shutdown, mobile health tent clinics treating protesters were set on fire, and female health workers were raped. ${ }^{3}$ In 2021, 870 people were killed and 430 ooo people have been displaced, in part, due to armed attacks. ${ }^{4}$ Violating international humanitarian law, ${ }^{1}$ these deliberate, methodical, widespread, and consistent tactics are still being used to repress popular dissent against the widely-rejected civilian-military deal that many believe was whitewashing the coup and legitimising violence perpetrators. With the armed forces continuing to kill pro-democracy demonstrators, the prime minister, Abdalla Hamdok, resigned, leaving the army in full control.

Health workers, within Sudan and the diaspora, remain instrumental to organising the protests and ensuring treatment of victims, with several associations who represent Sudanese doctors co-leading civil disobedience movements. Militias responded to anti-coup protests with unwarranted deadly force, ${ }^{5}$ falling back on honed tactics of raiding hospitals, firing on physicians and patients, as well as using teargas to prevent health workers from entering and treating victims. ${ }^{6}$ In the wake of a political agreement between the military and the then reinstated prime minister, in November 2021, the attacks on health care workers and facilities persisted, with patients and health workers still facing physical violence, threats, and intimidation, preventing them from receiving or providing care. ${ }^{6}$ In addition to interfering with healthcare, several doctors and activists have been detained, straining further an already overstretched health system.

It is important to note that, although familiar, the level and intensity of these tactics appear to have intensified when compared to protest movements against the Al-Bashir regime. Clinicians have detected "expanding" bullets-which have been banned internationally since 1899- while treating patients. ${ }^{7}$ Teargas canisters have been fired inside hospitals, interrupting surgeries and life-saving measures; unarmed protesters have also been targeted with a highly potent teargas agent, leading to death by suffocation. ${ }^{6}$ Fatal attacks were recently conducted in residential neighbourhoods and homes. ${ }^{6}$ According to the Central Committee of Sudanese Doctors, since the coup, militias have killed at least 76 civilians, including teenagers and physicians, and beaten, injured and arrested hundreds of teachers, civilians, journalists and politicians. ${ }^{6}$ Many are now critically ill and facing permanent disabilities. ${ }^{6}$

The intent to respond with widespread violence appears pre-meditated. Various reports demonstrate that snipers shoot at protesters from rooftops to precisely target their heads and chests ${ }^{8} ; 96 \%$ of all those killed were shot in the head, neck, chest or abdomen. ${ }^{9}$ To ensure that planned attacks occur without real-time documentation, the military shuts down internet and communication services nationally. This method of silencing an entire population, while leaders commit acts of violence, was previously used by the government intermittently between December 2018 and April 2019, and by the Transitional Military Council on 3 June 2019, when a bloody and large-scale attack was carried out on peaceful protesters. ${ }^{10}$

These abusive strategies render the provision of healthcare almost impossible. Political violence is also strongly linked to increased disease transmission and disruption of access to healthcare. In Syria, childhood immunisation programmes have been significantly hampered by healthcare attacks, leading to the re-emergence of polio almost 20 years after elimination status was achieved nationally. ${ }^{11}$ The virus also re-emerged in neighbouring Iraq which was polio-free for over 14 years. ${ }^{12}$ The Democratic Republic of Congo's armed conflicts led to the second largest Ebola outbreak, ${ }^{13}$ with the virus reaching neighbouring Uganda. ${ }^{14}$

Sudan already struggles with high morbidity and mortality from vaccine-preventable communicable diseases, especially in conflict-affected regions. ${ }^{15}$ Approximately 13 million people are living with life-threatening conditions ( $75 \%$ increase in one year) and almost 15 million people- $31 \%$ of the population-will require humanitarian assistance in $2022,{ }^{4}$ a statistic which may increase under the current circumstances which include the resignation of the top official at the Ministry of Health, Haitham Mohamed Ibrahim, in protest to the killings of demonstrators. Access to curative health services, which already face significant shortages of stocks, ambulances and paramedics, is now very limited. ${ }^{10}$ The suspension of preventative services, including the covid-19 vaccination programme, and testing and tracing, amid a new variant and rising cases indicative of a fourth wave, as well as routine 
childhood vaccination programmes, will lead to significant preventable deaths in the short- and long term. ${ }^{16}$ Outside the devastating impact on Sudan, the rise of infectious diseases may have serious implications on global health, particularly neighbouring Ethiopia, a country already facing an escalating humanitarian crisis.

The coup leaders' increasingly deadly habit of targeting health workers and peaceful protestors remains, with use of lethal force intensifying. Still, impunity for attacks on healthcare facilities and workers is widespread. We urge our fellow health and humanitarian professionals, across the world, to ensure the right to health for all Sudanese people and recognise the psychological trauma health workers remain subjected to by calling for an immediate end to violence, protection of all health personnel and facilities, and a restart of all essential health services under democratically elected leadership. It is time to denormalise the status quo.

Competing interests: none declared.

Provenance and peer review: not commissioned, not peer reviewed

1 Human Rights Watch. "Men With No Mercy" Rapid Support Forces Attacks against Civilians in Darfur, Sudan. 2015. Available from: https:/www.hrw.org/report/2015/09/09/men-no-mercy/rapidsupport-forces-attacks-against-civilians-darfur-sudan

2 Dahab M, Abdelmagid N, Osama T, etal. Political violence in Sudan: the need for a coordinated, locally led humanitarian health response. Lancet 2019;394:549-51. doi: 10.1016/S0140-6736(19)31618-6 pmid: 31301814

3 Devi S. Health targeted in Sudan's political transition. Lancet 2019;393:2380. doi: 10.1016/S0140-6736(19)31399-6 pmid: 31204667

4 UN Office for Coordination of Humanitarian Affairs. Sudan: Humanitarian Snapshot - September 2021 (as of 18 October 2021). 2021. Available from: https://reliefweb.int/report/sudan/sudanhumanitarian-snapshot-september-2021-18-october-2021

5 Human Rights Watch. Sudan: Immediately Free Detainees; Halt Arrests. 2021. Available from: https://www.hrw.org/news/2021/11/09/sudan-immediately-free-detainees-halt-arrests

6 Central Committee of Sudanese Doctors. IIID2021. Available from: https://www.theccsd.org/

7 Andrews F. Sudan coup: 15-year-old killed, security forces accused of using banned "expanding bullets". Middle East Eye. 2021. Available from: https://www.middleeasteye.net/news/sudancoup-15-year-old-killed-security-forces-accused-using-expanding-bullets

8 Amnesty International. Sudan: Investigate the killings of people after military crackdown against protesters. 2021. Available from: https://www.amnesty.org/en/latest/news/2021/11/sudan-investigate-the-killings-of-people-after-military-crackdown-against-protesters/

9 Benoist C, Andrews F. Sudan coup: The names and faces of the protesters killed. Middle East Eye. 2021. Available from: https://www.middleeasteye.net/news/sudan-coup-protesters-killednames-faces

10 Human Rights Watch. Sudan: End Network Shutdown Immediately. Internet Vital for Safety, Communications in Crisis. 2019. Available from: https://www.hrw.org/news/2019/06/12/sudanend-network-shutdown-immediately

11 Al-Moujahed A, Alahdab F, Abolaban H, Beletsky L. Polio in Syria: Problem still not solved. Avicenna J Med 2017;7:64-6.pmid: 28469988

12 Arie S. Polio virus spreads from Syria to Iraq. BMJ 2014;348:g2481. doi: 10.1136/bmi.g2481 pmid: 24696176

13 Shears P, Garavan C. The 2018/19 Ebola epidemic the Democratic Republic of the Congo (DRC): epidemiology, outbreak control, and conflict. Infect Prev Pract 2020;2:100038. doi: 10.1016/j.infpip.2020.100038 pmid: 34368690

14 UN Office for Coordination of Humanitarian Affairs. Uganda declares end of Ebola outbreak. 2019 Available from: https://reliefweb.int/report/uganda/uganda-declares-end-ebola-outbreak

15 World Health Organisation. Sudan Health Sector Fact Sheet. 2013. Available from: https://www.who.int/hac/sudan_healthsector_factsheet.pdf

16 Abbas K, Procter SR, van Zandvoort K, etalLSHTM CMMID COVID-19 Working Group. Routine childhood immunisation during the COVID-19 pandemic in Africa: a benefit-risk analysis of health benefits versus excess risk of SARS-CoV-2 infection. Lancet Glob Health 2020;8:e1264-72. doi: 10.1016/S2214-109X(20)30308-9 pmid: 32687792 